\title{
THE SCHOOL CLUB: ITS RELATION TO SEVERAL EDUCATIONAL IDEALS
}

A. MONROE STOWE, A.M., PH.D

State Normal School, Hyannis, Mass.

In endeavoring to realize one of the chief ideals of the public elementary schools, the development of intelligent, efficient, and upright citizens, teachers have had to depend upon the curriculum for material from which to develop a knowledge and appreciation of the rights and duties of citizens in a democracy and upon the classroom discipline for opportunities to make vital this knowledge through expression. While such studies as history, literature, geography, and civil government contain a wealth of material from which to develop such knowledge, the teacher is handicapped by the fact that as the government of the schoolroom must necessarily be of a more or less paternalistic character, the opportunities for the application or expression of this knowledge are very limited. Limitation in this case is unfortunate, since the realization of the ideal requires not only a knowledge and appreciation of the rights and duties of citizens in a democracy, but also a habitual proper reaction to those rights and duties. In other words, the intelligent, efficient, and upright citizen not only knows what he ought to do in a given civic situation, but he always actually does what he ought to do. Hence in this training for citizenship there should be training in citizenship, there should be opportunities to act and form habits of reacting as well as instruction in theory and principles. If, therefore, the schools are to be more successful in their endeavors to realize the ideal they have accepted, they must utilize every agency which makes possible growth in civic efficiency as well as improvement in civic knowledge.

Recognizing the fact that in this training for citizenship in a democracy there must be training in citizenship in a like democracy, not a few of thoughtful men welcomed the "school state," the "school city," and the "school village" as agencies 
which might make possible this necessary growth in civic efficiency. This movement, however, met with severe criticism. It was said that the movement created within the school an organization entirely too complex and artificial. Teachers and principals who were working for simplicity in school administration did not favor a scheme involving the complexity of the government of the modern state, city, or town. Why impose upon the school forms of government which are proving themselves cumbersome and unsatisfactory in real life? Such forms could never express the real vital life of the school which must be regarded, not as a civic community, but as a large family in which the teacher stands in loco parentis.

Granted that the school is like a large family the artificiality of the "school city" is very apparent. The "school city" is not a real city, nor are the pupils real citizens. While sometimes it may seem almost real, there must always be the realization that after all it is merely a game. The police are not real police. The police court is not a real police court; nor is the criminal (let us be thankful) the real criminal. It is all a play, sometimes a drama, sometimes perhaps a farce, in which the actors are little men and women. Is not this attempt to reproduce the state, city, or town in miniature, with little men and women as its citizens, a retrogression to the seventeenth-century conception of children? Must another Rousseau arise to awaken us again to the fact that children are children, not little men and women?

To reject the "school city," however, does not necessarily mean that we must henceforth depend upon the curriculum and school discipline alone for our material and practice in the development of our ideal. Training for citizenship still implies training in citizenship, but we must remember that the citizenship of the child is somewhat different from the citizenship of the adult. If our schools are to be made more real to the child, we must find some agency which will express a part of his life as well as make possible growth in civic efficiency through activity. Such an agency can be found only in a careful study of the natural development of the life of the child.

A careful study of the natural development of the child will 
reveal a period in his life when ceasing to live so completely for himself alone, he begins to reach out in an effort to join his life with the lives of others through some forms of co-operative activity. While at first this reaching out may be unconscious and instinctive and may express itself in gang life as well as friendships, it also becomes conscious, expressing itself in the club or society organized for the accomplishment of definite aims and purposes. At the threshold of this stage of their development the pupils of the last two years of the upper elementary schools stand, anxious to do things, and perceiving that some things can be accomplished only by working together in some form of club, they are eager to organize and enjoy the pleasure of achieving results through co-operation. Club life is to them, therefore, very real and vital. Not only is this true, but, as in the club they learn their first lessons in living and working together in a democratic organization, respecting the rights of others, while maintaining their own and performing their own duties while insisting that others shall not be negligent of theirs, we may almost say that the club is the youths' own state in which they learn the fundamental lessons of citizenship. Shall these lessons be learned only by the wasteful hit-and-miss method of experience or shall the pupils have the helpful guidance of the wise teacher? As the presentation of the proper motive by the teacher will set the pupils eagerly at work on the organization of a school club, it is within the power of the teacher, as advisor to such a club, to exercise this much needed guidance. Indeed, since the school club, when organized and conducted by the pupils, not only meets the need so long felt by the teacher in his endeavors to develop intelligent, efficient, and upright citizens, but also helps make school life more real and vital to the child, is it not the duty of the school to utilize this agency which expresses the civic life of the pupil as well as makes possible a natural and progressive growth in civic efficiency?

While from the point of view of the ideal of the school the function of the school club is to furnish opportunities for making vital through expression the knowledge of the rights and duties 
of citizens in a democracy acquired through their study of the subjects of the curriculum, from the standpoint of the individual pupil one' of the most important functions of the school club is to train its members in the knowledge and practice of parliamentary rules of order. How widespread ignorance concerning parliamentary procedure is among members of organizations of teachers and university post-graduate students, as well as of churches and women's clubs, is well known to those who are acquainted with the way in which the business of these organizations is often conducted or rather misconducted by the members, many of whom feel very deeply their inability not only to conduct meetings as they should be conducted but also to make or put even the most simple motions. Since this knowledge and power will be needed by the great majority of the graduates of our elementary schools, and since in these schools we are endeavoring to develop all of the powers of the individual, do we not owe it to the individual to develop his power and ability to co-operate with others in the conduct of meetings and in the transaction of business in the best ways, or according to recognized rules of order? Is it not the duty of the school to meet this real and vital need by developing in its pupils a working knowledge of these rules of procedure?

Granted that it is the duty of the schools to develop in its pupils a working knowledge of the standard rules of order, how shall the schools develop such knowledge? From the nature of the subject it is evident that formal instruction in it will be insufficient, since to make this knowledge vital requires opportunity to put into practice the knowledge thus acquired. From the nature of the child, furthermore, it is evident that this instruction and practice must not be artificial, since the result desired can be achieved only if the instruction be given in response to a need felt by the child and the practice be found in putting this knowledge to some practical use. As in the ordinary school there is no agency which either calls into being a need for this instruction or presents opportunities for the practical use of this knowledge, if the school is to be successful in giving this training, must it not make use of the school club, organized 
and conducted by the pupils for the purpose of achieving ends accepted by the child as worthy of his efforts and attainable only through co-operation?

Thus the school club both makes possible a natural and progressive growth in civic efficiency and furnishes opportunities for a vital development of a practical knowledge of the rules of order in such a way as to assist the school in its endeavors to make the school life an expression of the child's life as well as a better preparation for intelligent, efficient, and upright participation in the privileges and duties of American citizenship. 